\title{
EFFECT OF CHLORELLA VULGARIS ALGAE SUPPLEMENTATION ON GROWTH PERFORMANCE OF SUCKLING FRIESIAN CALVES. 18
}

\author{
A.Sh. Shams ${ }^{1}$; M.E. Sayed-Ahmed ${ }^{1}$; M.M. El-Nahrawey ${ }^{1}$; R.M. Abou-Aiana ${ }^{1}$ and A.Y. \\ Elsadany $^{2}$ \\ ${ }^{1}$ Animal Production Research Institute, Agricultural Research Center, Dokki, Giza, Egypt. \\ ${ }^{2}$ Soils, water, and Environment Research Institute, Agricultural Research Center, Giza, Egypt.
}

SUMMARY

$\mathrm{T}$

wenty newly born male and female Friesian calves with an average live body weight (LBW) of $30.40 \pm 0.36 \mathrm{~kg}$ were divided into five similar groups ( 2 male +2 female in each group) and continued in a feeding trial until weaning to study the effect of supplementing the algae on suckling calves growth performance. Diet of cows and their suckling calves in G1 did not supplemented with algae and served as a control diet. Whereas, cows and their suckling calves were supplemented with algae and their media at levels of $2 \mathrm{ml}$ (G2) and $4 \mathrm{ml}$ (G3) / kg LBW, as low and high levels, respectively. While, cows in G4 and G5 were unsupplemented with algae, but their suckling calves were supplemented with Chlorella vulgaris algae and their media at the same above levels. Results showed that groups supplemented with high level of algae (G3 and G5) were recorded significantly $(\mathrm{P}<0.05)$ the highest digestibility of all nutrients and feeding values followed by groups supplemented with low level of algae (G2 and G4), while control group (G1) had the lowest values. The DMI were the same for different groups, while the intake of TDN and DCP were significantly $(\mathrm{P}<0.05)$ higher for G3 and G5 compared to those of control one $(\mathrm{G} 1)$, but the low levels of algae rations (G2 and G4) were insignificant higher than those of control ration as well. Mostly, blood serum measurements (total protein, globulin and albumin) in addition of creatinine and liver enzymes activity (AST and ALT) were markedly improved versus to those of control group (G1). Moreover, the concentrations of immunoglobulin fractions (IgA, IgM and $\mathrm{IgG})$ were increased significantly $(\mathrm{P}<0.05)$ with chlorella supplementation and increased with increasing the level of chlorella supplement. Weaning weight and average daily gain of suckling calves increased significantly $(\mathrm{P}<0.05)$ with chlorella algae supplementation as well as with increasing supplementation level. Chlorella supplementation improved significantly $(\mathrm{P}<0.05)$ feed conversion, being decreased the amounts of DM, TDN and DCP required per one $\mathrm{kg}$ live weight gain. Also, chlorella supplementation improved economic efficiency, which decreased feed cost per one kg live weight gain and increased the total and net revenue of live weight gain and economic efficiency.

Keywords: suckling calves, Chlorella algae supplementation, digestibility, growth performance and economic efficiency.

\section{INTRODUCTION}

Microalgae are photosynthetic microorganisms that have the ability to convert sunlight and carbon dioxide $\left(\mathrm{CO}_{2}\right)$ to highly valuable biomass. Algal biomass production has advantages such as use of water that is unsuitable for humans and minimum competition for land with crops. Due to their contents of essential amino acids, fatty acids and other health promoting nutrients, microalgae are attractive feeds or feed supplements for livestock (Janczyk et al., 2006). Chlorella is a genus of single-celled green algae belonging to the division Chlorophyta. It is spherical in shape, about 2 to $10 \mu \mathrm{m}$ in diameter, and is without flagella. Chlorella contains the green photosynthetic pigments chlorophyll-a and $-b$ in its chloroplast. Through photosynthesis, it multiplies rapidly, requiring only carbon dioxide, water, sunlight, and a small amount of minerals (Scheffler, 2007).

Chlorella vulgaris (C. vulgaris) is a genus of unicellular green algae containing high level of protein (50 to $70 \%$ of dry matter), lipid, vitamins and minerals (Phang, 1992). Chlorella vulgaris is a single-celled freshwater microalgae and contains the highest amount of chlorophyll of any common plant, with protein content of about $600 \mathrm{~g} / \mathrm{kg}$ dry matter (DM) and 18 amino acids as well as vitamins and minerals (Radhakrishnan et al., 2014). Abedin and Taha (2008) had previously suggested that C. vulgaris have a higher antimicrobial activity due to the presence of cyclic peptides, alkaloids, and lipopolysaccharides in vitro. Janczyk et al. (2009) also suggested that the inclusion of C. vulgaris could benefit the intestinal 
lactobacillus diversity in laying hens because of the unknown compounds such as polysaccharides, phenolic substances and aromatic compound (Halama, 1990).

Even when used at small amounts in livestock and aquaculture feeds, algae have been credited with improving immune system (Turner et al. 2002), lipid metabolism (Nakagawa, 1997 and Güroy et al., 2011), antiviral and antibacterial action, improved gut function (Michiels et al., 2011), stress resistance (Nath et al., 2012 and Sheikhzadeh et al., 2012) besides providing a source of protein, amino acids, fatty acids, vitamins and minerals, and other biologically active phytochemicals (Pulz and Gross, 2004; Becker, 2004 and Gouveia et al., 2008).

Microalgae are well provided sources of vitamins, fundamental amino acids, minerals, vital fatty acids, and carotenoid pigments for aquatic animals (Takeuchi et al., 2002). Many kinds of microalgae used in feeding trials with fish led to an increase of growth performance (protein accretion), feed utilization, physiological activity, stress response, starvation tolerance, disease resistance, carcass quality (Mustafa and Nakagawa, 1995), carotenoid and protein sources for shrimp (Patnaik et al., 2006; Regunathan and Wesley, 2006). Moreover, it contains some other important dietary components such as unsaturated fatty acids (UFA), glycoproteins and carotenoids (Janczyk et al., 2006). Chlorella vulgaris contains a phyto-nutrient called Chlorella Growth Factor (CGF), comprised mainly of nucleic acids and other essential substances, with detoxification and antioxidant properties (Han et al., 2002). Two recent studies (Anele et al., 2016 and Tsiplakou et al., 2016) reported that $C$. vulgaris improved bacterial growth and a shift in the ruminal biohydrogenation pathway by stimulating production of trans $\mathrm{C} 18: 1$, trans-11 C18:1 fatty acids, monounsaturated (MUFA) and polyunsaturated fatty acids (PUFA).

Chlorella as a feed supplement has been known to have beneficial effects, such as growth, immunomodulation, antioxidant activity and tissue rebuilding (Guzmán et al., 2001).

The objective of this study was to investigate the effect of orally adding of fresh chlorella algae with their media on feed intake, digestibility, blood biochemical and immunoglobulin fractions parameters, body weight gain, feed conversion and economic efficiency of suckling Friesian calves.

\section{MATERIALS AND METHODS}

This study was carried out at El-Karada Animal Production Research Station, Kafr El-Sheikh Governorate, belonging to Animal Production Research Institute, Agricultural Research Center, Ministry of Agriculture and Land Reclamation.

\section{Chlorella vulgaris microalgae:}

Lyophilized C. vulgaris biomass was cultivated in Cyanobacteria Research Lab., Microbiology Dept., Sakha Agricultural Research Station, Soils, water, and Environment Research Institute, Kafr El-Sheikh, Egypt. Inoculum was prepared as described by El-Sayed et al. (2001) using BG-II growth medium (Stainer et al., 1971). Continuous light illumination was provided from daylight lamps $(10 \times 40 \mathrm{w})$. Aeration was achieved using an oil-free air compressor (HIBLOW AIR PUMP, type SPP-100GJ-H, Japan) through a 3$\mathrm{mm}$ polyethylene tube. Room temperature was adjusted to $27 \pm 2{ }^{\circ} \mathrm{C}$ during the whole incubation period. Incubation was carried out using fully transparent polyethylene bags $(75 \times 5 \mathrm{~cm} 2$ and $100 \mu \mathrm{m}$ thickness $)$ containing 2.5 liters of algal broth. Mass production of C. vulgaris was performed within a 1000-litre Zigzag photobioreactor (El-Sayed et al., 2015). For harvesting and cleaning of the obtained biomass, a series of precipitation and washing was performed using tap water and a cooling centrifuge (RUNNE, HIDEBERG, RSV-20, Germany).

\section{Animals and experimental groups:}

Twenty newly born male and female Friesian calves with an average live body weight (LBW) of $30.40 \pm 0.36 \mathrm{~kg}$ were divided into five similar groups ( 2 male +2 female in each group) and continued in a feeding trial until weaning. Diet of cows and their suckling calves in G1 did not supplemented with algae and served as a control diet. Whereas, cows and their suckling calves were supplemented with algae and their media at levels of $2 \mathrm{ml}(\mathrm{G} 2)$ and $4 \mathrm{ml}(\mathrm{G} 3) / \mathrm{kg} \mathrm{LBW}$, as low and high levels, respectively. While, cows in G4 and G5 were unsupplemented with algae, but their suckling calves were supplemented with Chlorella vulgaris algae and their media at the same above levels. 


\section{Management procedures:}

Dams of calves in G2 and G3 were orally administrated with chlorella algae every day at the low and high levels of 2 and $4 \mathrm{ml} / \mathrm{kg} \mathrm{LBW}$, respectively. Calves were left with dams to suckle their dam's colostrum during the first three days after calving. After that, calves were housed in separate pins at night and free in backyard at day. Calves were fed their allowance during the suckling period (105 days) to cover their nutritional requirements according to NRC (2001) as shown in Table (1). Calves were individually suckled the whole milk in plastic buckets two times daily at 7 a.m. and 4 p.m. Whereas, they were fed in group feeding on calf starter (CS) once time at 8 a.m. and berseem hay (BH) at 11 a.m. Chlorella algae was orally administrated for suckling calves. Fresh water was free available for calves all the day round. Calf starter was consisted (as fed) of 20\% soybean meal, 5\% linseed cake, 34\% ground yellow corn grain, 20\% wheat bran, $15 \%$ rice bran, $3 \%$ molasses, $2 \%$ limestone and $1 \%$ common salt. Chemical compositions of different feedstuffs are shown in Table (2).

Table (1): Daily allowances of whole milk, starter, berseem hay for suckling Friesian calves.

\begin{tabular}{ccccc}
\hline \multirow{2}{*}{ Age } & \multicolumn{2}{c}{ Whole milk $(\mathrm{kg})$} & $\begin{array}{c}\text { Calf starter } \\
(\mathrm{g})\end{array}$ & $\begin{array}{c}\text { Berseem hay } \\
(\mathrm{g})\end{array}$ \\
\cline { 2 - 3 } 1-3 days & Morning & Evening & Suckling their dam's colostrum & - \\
4-7 days & 2 & 2 & 50 & 50 \\
Week 2 & 2.5 & 2 & 100 & 100 \\
Week 3 & 3 & 2 & 150 & 150 \\
Week 4 & 3 & 3 & 200 & 200 \\
Week 5 & 3 & 2.5 & 250 & 250 \\
Week 6 & 3 & 2 & 300 & 300 \\
Week 7 & 2.5 & 2 & 350 & 350 \\
Week 8 & 2.5 & 2 & 400 & 400 \\
Week 9 & 2 & 2 & 450 & 450 \\
Week 10 & 3 & - & 500 & 500 \\
Week 11 & 3 & - & 600 & 600 \\
Week 12 & 3 & - & 700 & 700 \\
Week 13 & 2 & - & 800 & 800 \\
Week 14 & 2 & - & 900 & 900 \\
Week 15 & 1 & - & 1000 & \\
\hline
\end{tabular}

Table (2): Chemical composition of calf starter and berseem hay.

\begin{tabular}{lccccccc}
\hline \multirow{2}{*}{ Item } & \multirow{2}{*}{ DM \% } & \multicolumn{7}{c}{ Composition of DM \% } \\
\cline { 3 - 8 } & & OM & CP & CF & EE & NFE & Ash \\
\hline Calf starter & 90.03 & 89.79 & 18.40 & 5.92 & 2.40 & 63.07 & 10.21 \\
Berseem hay & 88.83 & 85.67 & 14.81 & 30.11 & 2.13 & 38.62 & 14.33 \\
Basal diet* & 26.49 & 90.13 & 19.34 & 11.05 & 13.46 & 46.28 & 9.87 \\
\hline
\end{tabular}

The composition of whole milk was $3.94 \%$ fat, $2.86 \%$ protein, $4.32 \%$ lactose, $7.88 \%$ solids not fat, $11.82 \%$ total solids and $0.70 \%$ ash.

* Basal diet contained whole milk + calf starter + berseem hay.

\section{Live body weight:}

Calves were weighed weekly in the morning before drinking and feeding to the nearest $0.1 \mathrm{~kg}$ for each animal during the suckling period and the average daily body weight gain were calculated.

\section{Digestibility trials:}

Five digestibility trials were conducted at the end week of the suckling period using all calves to determine nutrient digestion coefficients and feeding values of the experimental diets. Acid insoluble ash (AIA) was used as a natural marker as described by Van Keulen and Young (1977). Feces samples were taken from the rectum of each calf twice daily with 12 hours interval for 7 days collection period. Milk samples were analyzed for fat, protein, lactose, solids not fat (SNF), and total solids (TS) by Milko-Scan (model 133B), and ash by difference. While, samples of calf starter, berseem hay and feces were dried in a forced air oven at $65{ }^{\circ} \mathrm{C}$ for 48 hours, ground and representative samples were carried out according to the 
methods of AOAC (2000). Digestibility coefficient of all nutrients was calculated from the equation given by Schneider and Flatt (1975).

\section{Blood samples:}

Blood samples were collected from all calves at the end week of suckling period by direct jugular vein puncture into tubes with serum cloth activator (Meus, Piove di Sacco, Italy). Blood samples were allowed to clot at room temperature and then centrifuged at $3000 \mathrm{rpm}$ for 30 minutes to separate serum. The harvested blood serum was dispensed into plastic tubes and stored at $-20^{\circ} \mathrm{C}$ until analyses. Total protein, albumin, globulin (total protein - albumin), creatinine, aspartate aminotransferase (AST) and alanine aminotransferase (ALT) were determined calorimetrically by spectrophotometer (Spectronic 21D, USA) using commercial kits produced by Diagnostic System Laboratories, Inc., USA. The concentrations of immunoglobulin fractions (IgA, IgM and IgG) in blood serum samples were measured using the quantitative ELISA Bovine (IgG), ELISA Quantitation Kit, Bethyl laboratories, UK.

\section{Feed conversion:}

Feed conversion was expressed as the amount of DM, TDN and DCP required per one kg weight gain.

\section{Economic efficiency:}

Economic efficiency parameters were calculated according to the prices of year 2018. The prices in Egyptian pound (LE) per ton were $5500 \mathrm{LE}$ for calf starter and $3000 \mathrm{LE}$ for berseem hay. Also, the prices per $\mathrm{kg}$ were $5 \mathrm{LE}$ for milk and $70 \mathrm{LE}$ for live weight gain. Whereas the price of chlorella algae with media was $4 \mathrm{LE}$ for one liter.

\section{Statistical analysis:}

The data of were statistically analyzed using general linear model procedure adapted by IBM SPSS Statistics (2014) for user's guide with one-way ANOVA. Significant differences in the mean values among dietary treatments were analyzed by Duncan's tests within SPSS program set at the level of significance $\mathrm{P}<0.05$ (Duncan, 1955).

\section{RESULTS AND DISCUSSION}

\section{Nutrients digestibility and feeding values:}

Results of nutrients digestibility and feeding values for the different experimental rations are presented in Table (3). Rations supplemented with the high level of chlorella algae (G3 and G5) were recorded significantly $(\mathrm{P}<0.05)$ the highest values of digestibility for all nutrients and feeding values followed by $\mathrm{G} 2$ and G4 those received the low level of chlorella algae, whereas the control one (G1) had significantly the lowest values. Digestibility of all nutrients and feeding values increased by $2.49-2.80 \%$ with low level versus 5.49-6.00\% with the high level of chlorella algae compared to the control one. The determination of digestibility coefficients is the first step in evaluating the nutritional quality and utilization efficiency of an ingredient in complete diets for animals. These measurements provide an indication of the nutrients or energy fraction of the ingested feedstuffs that are not excreted in the feces, but are used for metabolic processes for animal production (NRC, 2011), thereby positively affecting production rates. It has been suggested that the Chlorella contained growth promoting substance such as S-nucleotide adenosyl peptide complex, which may affect digestibility of the animals (Han et al., 2002). Supplementation of animal feeds with acceptable levels of Chlorella biomass can have a positive influence and probably associated with improvement of nutrients digestibility in pigs (Yan et al.,2012), as well as with higher utilization of minerals (Taranu et al., 2012). Zeinhom (2004) found that fish fed diet containing 15\% algae increased significant by the digestibility coefficient of dry matter, crude protein, ether extract and energy. Cholerlla vulgaris contains $\beta$-glucan, which plays a role in scavenging free radicals (Iwamoto, 2004) and thus improves fermentation. Moreover, the $C$. vulgaris microalgae contents of PUFA, carotenoids, phycobiliproteins, polysaccharides and phycotoxins are required for higher microbial growth (Kotrbáček et al., 2015). Tibbetts et al. (2016) reported that the dietary effect of algal supplementation on feed digestibility in ruminants is related in part to its lipid content. Two recent studies (Anele et al., 2016 and Tsiplakou et al., 2016) reported that C. vulgaris improved bacterial growth and a shift in the ruminal biohydrogenation pathway by stimulating production of trans C18:1, trans-11 C18:1 fatty acids, monounsaturated (MUFA) and polyunsaturated fatty acids (PUFA). 
Kholif et al. (2017) reported that Chlorella vulgaris supplementation to the diet of goats increased apparent diet digestibility compared with a control diet.

Table (3): Nutrients digestibility and feeding values for the experimental rations.

\begin{tabular}{|c|c|c|c|c|c|c|}
\hline \multirow{2}{*}{ Item } & \multicolumn{5}{|c|}{ Experimental groups } & \multirow{2}{*}{ SEM } \\
\hline & G1 & G2 & G3 & G4 & G5 & \\
\hline \multicolumn{7}{|c|}{ Nutrients digestibility, $\%$} \\
\hline $\mathrm{DM}$ & $68.54^{\mathrm{c}}$ & $70.46^{\mathrm{b}}$ & $72.65^{\mathrm{a}}$ & $70.25^{\mathrm{b}}$ & $72.31^{\mathrm{a}}$ & 0.43 \\
\hline $\mathrm{OM}$ & $69.76^{\mathrm{c}}$ & $71.71^{\mathrm{b}}$ & $73.95^{\mathrm{a}}$ & $71.50^{\mathrm{b}}$ & $73.60^{\mathrm{a}}$ & 0.44 \\
\hline $\mathrm{CP}$ & $68.35^{\mathrm{c}}$ & $70.26^{\mathrm{b}}$ & $72.45^{\mathrm{a}}$ & $70.06^{\mathrm{b}}$ & $72.11^{\mathrm{a}}$ & 0.42 \\
\hline $\mathrm{CF}$ & $61.17^{\mathrm{c}}$ & $62.88^{\mathrm{b}}$ & $64.84^{\mathrm{a}}$ & $62.70^{\mathrm{b}}$ & $64.53^{\mathrm{a}}$ & 0.38 \\
\hline $\mathrm{EE}$ & $76.93^{c}$ & $79.08^{b}$ & $81.55^{\mathrm{a}}$ & $78.85^{\mathrm{b}}$ & $81.16^{\mathrm{a}}$ & 0.48 \\
\hline NFE & $70.28^{c}$ & $72.25^{\mathrm{b}}$ & $74.50^{\mathrm{a}}$ & $72.04^{\mathrm{b}}$ & $74.15^{\mathrm{a}}$ & 0.44 \\
\hline \multicolumn{7}{|c|}{ Feeding values, $\%$} \\
\hline TDN & $75.80^{\mathrm{c}}$ & $77.92^{\mathrm{b}}$ & $80.35^{\mathrm{a}}$ & $77.70^{\mathrm{b}}$ & $79.97^{\mathrm{a}}$ & 0.47 \\
\hline $\mathrm{DCP}$ & $13.22^{\mathrm{c}}$ & $13.59^{\mathrm{b}}$ & $14.01^{\mathrm{a}}$ & $13.55^{\mathrm{b}}$ & $13.95^{\mathrm{a}}$ & 0.08 \\
\hline
\end{tabular}

\section{Feed intake:}

Feed intake by suckling calves are presented in Table (4) where the values revealed that the intake of the different ingredients as well as DM intake were typically comparable for the different dietary treatments. These results may be due to that calves in the different groups were fed their recommended requirements according to NRC (2001) as well as they were run in group feeding for calf starter and berseem hay. Whereas, the intake of TDN and DCP were significantly $(\mathrm{P}<0.05)$ higher in G3 and G5 which received the high level of chlorella algae ( $4 \mathrm{ml} / \mathrm{kg}$ ) compared to those of control one, while $\mathrm{G} 2$ and $\mathrm{G} 4$ which received the low level of chlorella algae $(2 \mathrm{ml} / \mathrm{kg}$ ) were have the intermediate values without significant differences with the control. In spite of DM intake was the same for different groups, the increase of TDN and DCP intake with chlorella supplementation could be attributed to the increase TDN and DCP contents for groups received chlorella algae (Table 3). These results agreed with those obtained by Glover et al. (2012) observed that supplementing diets of lactating cows with marine microalgae at $200 \mathrm{~g} /$ day did not affect DMI of fresh forage or silage-based total mixed ration. However, Kholif et al. (2017) reported that Chlorella vulgaris treatments increased feed intake. Inconsistency between these studies may be due to different diet composition and different algae inclusion doses (Reynolds et al., 2006).

Table (4): Daily feed intake (kg/head/day) for calves of different experimental diets.

\begin{tabular}{lcccccc}
\hline \multirow{2}{*}{ Item } & \multicolumn{7}{c}{ Experimental groups } & \multirow{2}{*}{ SEM } \\
\cline { 2 - 5 } & $\mathrm{G} 1$ & $\mathrm{G} 2$ & $\mathrm{G} 3$ & $\mathrm{G} 4$ & G5 & \\
\hline Milk & 3.69 & 3.69 & 3.69 & 3.69 & 3.69 \\
Calf starter & 0.45 & 0.45 & 0.45 & 0.45 & 0.45 & \\
Berseem hay & 0.41 & 0.41 & 0.41 & 0.41 & 0.41 & \\
Chlorella algae (ml) & - & 115.32 & 240.35 & 116.33 & 237.85 & \\
DM & 1.21 & 1.21 & 1.21 & 1.21 & 1.21 & \\
TDN & $0.92^{\mathrm{b}}$ & $0.94^{\mathrm{ab}}$ & $0.97^{\mathrm{a}}$ & $0.94^{\mathrm{ab}}$ & $0.97^{\mathrm{a}}$ & 0.01 \\
DCP & $0.160^{\mathrm{b}}$ & $0.164^{\mathrm{ab}}$ & $0.170^{\mathrm{a}}$ & $0.164^{\mathrm{ab}}$ & $0.169^{\mathrm{a}}$ & 0.001 \\
\hline
\end{tabular}

$a$ and $b$ : Values in the same row with different superscripts differ significantly $(P<0.05)$.

\section{Blood serum biochemical:}

Blood serum biochemical of calves in the different groups are presented in Table (5). Almostly, there were significant $(\mathrm{P}<0.05)$ differences in the concentrations of total protein, albumin, globulin and creatinine in blood serum among the tested rations and control one. Total protein concentration was significantly $(\mathrm{P}<0.05)$ higher in G3 and G5 compared to G1, whereas the values of G2 and G4 were insignificant increased than the control one (G1). However, albumin concentration was significantly $(\mathrm{P}<0.05)$ lower in $\mathrm{G} 2$ than that of the control one (G1), whereas the concentrations of G3, G4 and G5 were insignificant lower than that of control (G1). At the same time, globulin concentration increased significantly $(\mathrm{P}<0.05)$ with Chlorella supplementation of all tested rations compared to the control one. Albumin to globulin ratio was 


\section{Shams et al.}

significantly $(\mathrm{P}<0.05)$ higher in G1 $(1.08)$ compared to the other groups $(0.88-0.93)$. Albumin to globulin ratio in groups received chlorella improved calves health, which were within the normal range for good health being 0.80 to 0.95 . Creatinine concentration decreased significantly $(\mathrm{P}<0.05)$ with chlorella supplementation than that of control. Live enzymes activity (AST and ALT) improved markedly $(\mathrm{P}<0.05)$ with Chlorella supplementation especially in G2 and G3. Increased serum total protein with C. vulgaris supplementation may be due to increased DCP intake. Reduced concentrations of AST and ALT are considered as important indicators for liver activity, functionality and hepatotoxicity, suggesting the absence of pathological lesions in the liver. In the present study, feeding $C$. vulgaris microalgae, at both levels, resulted in a significant decrease in AST and ALT concentrations, indicating a probable protective role for Chlorella vulgaris against liver dysfunction. Increased serum total protein with $C$. vulgaris supplementation may be due to increased CP and OM intakes and digestibilities. In addition, decreased values of serum urea$\mathrm{N}$ with different $C$. vulgaris treatments indicate the absence of protein catabolism, and normal kidney function (Hosten, 1990). Reduced concentrations of GPT and GOT are important indicators of liver activity, function and hepatotoxicity, suggesting the absence of pathological lesions in the liver. In the present study, feeding $C$. vulgaris microalgae, at both levels, resulted in a significant decrease in GPT and GOT concentrations, indicating a probable protective role for $C$. vulgaris against liver dysfunction. Kholif et al. (2017) reported that Chlorella vulgaris treatments increased serum total protein concentration but decreased serum AST and ALT concentrations. Also, El-Abd and Hamouda (2017) found that watering chickens with algae caused a reduction in creatinine, AST and ALT.

Table (5): Blood serum biochemical and immunoglobulin fractions of calves in the different groups.

\begin{tabular}{lcccccc}
\hline \multirow{2}{*}{ Item } & \multicolumn{7}{c}{ Experimental groups } & \multirow{2}{*}{ SEM } \\
\cline { 2 - 5 } & G1 & G2 & G3 & G4 & G5 & \\
Biochemical & & & & & \\
Total protein, g/dl & $7.17^{\mathrm{b}}$ & $7.22^{\mathrm{ab}}$ & $7.38^{\mathrm{a}}$ & $7.20^{\mathrm{ab}}$ & $7.35^{\mathrm{a}}$ & 0.03 \\
Albumin, g/dl & $3.72^{\mathrm{a}}$ & $3.37^{\mathrm{b}}$ & $3.53^{\mathrm{ab}}$ & $3.46^{\mathrm{ab}}$ & $3.45^{\mathrm{ab}}$ & 0.06 \\
Globulin, g/dl & $3.45^{\mathrm{b}}$ & $3.85^{\mathrm{a}}$ & $3.86^{\mathrm{a}}$ & $3.74^{\mathrm{a}}$ & $3.90^{\mathrm{a}}$ & 0.05 \\
Albumin/globulin ratio & $1.08^{\mathrm{a}}$ & $0.88^{\mathrm{b}}$ & $0.91^{\mathrm{b}}$ & $0.93^{\mathrm{b}}$ & $0.88^{\mathrm{b}}$ & 0.01 \\
Creatinine, mg/dl & $1.30^{\mathrm{a}}$ & $1.06^{\mathrm{b}}$ & $1.10^{\mathrm{b}}$ & $1.13^{\mathrm{b}}$ & $1.14^{\mathrm{b}}$ & 0.04 \\
AST, IU/L & $35.33^{\mathrm{a}}$ & $31.00^{\mathrm{b}}$ & $30.00^{\mathrm{b}}$ & $33.33^{\mathrm{ab}}$ & $33.00^{\mathrm{ab}}$ & 0.83 \\
ALT, IU/L & $16.50^{\mathrm{a}}$ & $12.83^{\mathrm{b}}$ & $13.17^{\mathrm{ab}}$ & $14.50^{\mathrm{ab}}$ & $14.33^{\mathrm{ab}}$ & 0.23 \\
Immunoglobulin fractions & & & & & \\
IgA, mg/dl & $28.00^{\mathrm{b}}$ & $32.42^{\mathrm{ab}}$ & $34.47^{\mathrm{a}}$ & $32.67^{\mathrm{ab}}$ & $34.50^{\mathrm{a}}$ & 0.56 \\
IgM, mg/dl & $7.56^{\mathrm{c}}$ & $9.83^{\mathrm{b}}$ & $10.77^{\mathrm{ab}}$ & $10.15^{\mathrm{ab}}$ & $11.82^{\mathrm{a}}$ & 0.37 \\
IgG, mg/dl & $120.92^{\mathrm{b}}$ & $138.33^{\mathrm{a}}$ & $140.33^{\mathrm{a}}$ & $141.83^{\mathrm{a}}$ & $140.58^{\mathrm{a}}$ & 1.73 \\
\hline
\end{tabular}

$a, b$ and $c$ : Values in the same row with different superscripts differ significantly $(P<0.05)$.

\section{Immunoglobulin fractions:}

Results in Table $(5)$ showed significant $(\mathrm{P}<0.05)$ increases in the concentrations of immunoglobulin fractions in blood serum with chlorella supplementation. The concentration of $\operatorname{IgA}$ was significantly $(\mathrm{P}<0.05)$ higher in serum of G3 and G5 (high chlorella level) compared to that of G1, whereas in G2 and G4 (low chlorella level), the IgA values were insignificant increased in relation with that of control (G1). While the concentration of IgM was significant higher for all tested rations in comparison with control one being the highest value was associated with G5. In respect of IgG, its concentration was significant higher with all algae rations than that of control one. Even when used such algae at small amounts in livestock and aquaculture feeds, a favorable affect have been credited with improving immune system (Turner et al., 2002). Guzmán et al. (2003) reported that chlorella as a feed supplement has been known to have beneficial effect on immuno-modulation, antioxidant activity and tissue rebuilding. Moreover, Taranu et al. (2012) found that natural supplements such as Chlorella vulgaris $(1 \%)$, sodium alginate $(0.1 \%)$, inulin $(1.5 \%)$, and a mixture of essential oils $(0.04 \%)$ had the ability to potentiate the immune function during the initial post weaning period. Dietary supplementation of $1 \%$ chlorella in the form of Chlorella Growth Factor (CGF) and as fresh liquid chlorella increased immune characteristics (number of lymphocytes) and population of Lactobacillus in broiler chickens (Kang et al., 2013).

\section{Live body weight and daily gain:}


Live body weight (LBW) and average daily gain (ADG) of calves fed the dietary treatments during suckling period are presented in Table (6). The initial weight (birth weight) was nearly similar for the different groups. Chlorella supplementation (all tested rations) revealed significant $(\mathrm{P}<0.05)$ increase in live body weight at 5,10 and 15 weeks of age in comparison with the unsupplemented one (control). Calves in G3, G4 and G5 showed significantly $(\mathrm{P}<0.05)$ higher LBW at 5 weeks of age compared to that of control one, whereas the LBW of G2 was insignificant higher than that of control (G1). In the same time, LBW of calves in groups received chlorella algae at 10 and 15 weeks of age was significantly $(\mathrm{P}<0.05)$ higher than that of control one. Moreover, calves in G3 and G5 (high chlorella level) recorded significantly $(\mathrm{P}<0.05)$ the highest LBW at weaning (15 week of age) followed by G2 and G4 (low chlorella level), while G1 had the lowest weight.

Concerning average daily gain (Table 6), results showed that ADG during the first 5 weeks of age (1-5) was higher significantly $(\mathrm{P}<0.05)$ in G3, G4 and G5 compared with G1, while G2 was insignificant higher than that of control (G1). Otherwise, ADG of calves at 10 weeks of age was higher significantly $(\mathrm{P}<0.05)$ in G2, G3 and G5 compared with G1, while G4 was placed at intermediate with insignificant difference with control or the other tested rations. Moreover, ADG during the third 5 weeks of age (11-15) was significantly $(\mathrm{P}<0.05)$ higher in G3 compared with G1, G2 and G4, but G5 was insignificant higher than control. Totally, high chlorella level $(\mathrm{G} 3$ and $\mathrm{G} 5)$ revealed significantly $(\mathrm{P}<0.05)$ the highest ADG over the whole suckling period followed by low chlorella level (G2 and G4), whereas G1 had the lowest ADG. These results are in agreement with those obtained by Guzmán et al. (2001) who found that chlorella as a feed supplement has been known to have beneficial effects on growth performance. Additionally, Yan et al. (2012) indicated that fermented chlorella supplementation could improve the growth performance of pigs. Recent studies have investigated the potential health benefits of Chlorella to improve the growth and productivity of birds by increasing their intestinal microbial population (Janczyk et al., 2009; Zheng et al., 2012 and Kang et al., 2013).

Table (6): Live body weight of suckling calves fed the different experimental rations.

\begin{tabular}{|c|c|c|c|c|c|c|}
\hline \multirow{2}{*}{ Item } & \multicolumn{5}{|c|}{ Experimental group } & \multirow{2}{*}{ SEM } \\
\hline & G1 & $\mathrm{G} 2$ & G3 & G4 & G5 & \\
\hline \multicolumn{7}{|c|}{ Live body weight $(\mathrm{kg})$} \\
\hline Birth & 30.30 & 30.32 & 30.68 & 30.43 & 30.28 & 0.26 \\
\hline 5 week & $42.00^{\mathrm{b}}$ & $43.53^{\mathrm{ab}}$ & $44.78^{\mathrm{a}}$ & $45.20^{\mathrm{a}}$ & $44.63^{\mathrm{a}}$ & 0.39 \\
\hline 10 week & $60.04^{\mathrm{b}}$ & $64.13^{\mathrm{a}}$ & $66.14^{\mathrm{a}}$ & $64.85^{\mathrm{a}}$ & $66.34^{\mathrm{a}}$ & 0.64 \\
\hline 15 week (weaning) & $80.20^{\mathrm{c}}$ & $85.00^{\mathrm{b}}$ & $89.50^{\mathrm{a}}$ & $85.90^{\mathrm{b}}$ & $88.65^{\mathrm{a}}$ & 0.80 \\
\hline \multicolumn{7}{|c|}{ Average daily gain $(\mathrm{kg})$} \\
\hline $1-5$ week & $0.33^{\mathrm{b}}$ & $0.38^{\mathrm{ab}}$ & $0.40^{\mathrm{a}}$ & $0.42^{\mathrm{a}}$ & $0.41^{\mathrm{a}}$ & 0.01 \\
\hline 6-10 week & $0.52^{\mathrm{b}}$ & $0.59^{\mathrm{a}}$ & $0.61^{\mathrm{a}}$ & $0.56^{\mathrm{ab}}$ & $0.62^{\mathrm{a}}$ & 0.01 \\
\hline $11-15$ week & $0.58^{\mathrm{b}}$ & $0.60^{\mathrm{b}}$ & $0.67^{\mathrm{a}}$ & $0.60^{\mathrm{b}}$ & $0.64^{\mathrm{ab}}$ & 0.01 \\
\hline $1-15$ week & $0.48^{\mathrm{c}}$ & $0.52^{\mathrm{b}}$ & $0.56^{\mathrm{a}}$ & $0.53^{\mathrm{b}}$ & $0.57^{\mathrm{a}}$ & 0.01 \\
\hline
\end{tabular}

\section{Feed conversion:}

Data of feed conversion expressed as the amounts of DM, TDN and DCP required per kg live weight gain are presented in Table (7). Chlorella algae supplementation improved significantly $(\mathrm{P}<0.05)$ the feed conversion efficiency. All chlorella-algae-rations were recorded significant higher feed conversion efficiency in comparison with control ration, being the lowest amounts of DM, TDN and DCP per one $\mathrm{kg}$ live weight gain were recorded with G3 and G5 rations, followed by G2 and G4 rations, while the control ration had the highest amounts of feed/1 kg of gain. These results are in accordance with those obtained by Mustafa and Nakagawa (1995) who reported that algae potentially contributed to an increased in feed utilization by fish. Duck feed supplemented with 0.2 and $0.3 \%$ Chlorella resulted in better nutrient utilization and reduced mortality rates (Redel and Buchta, 2001a,b). Also, Storandt et al. (2000) reported a positive effect of Chlorella on feed utilization by piglets, with $1 \%$ supplementation being the most effective. Furthermore, Jahn et al. (1995) found that feed supplementation of 1\% chlorella for 4- to 6-week-old piglets improved feed intake by $11.8 \%$ and feed conversion by $13.6 \%$.

\section{Economic efficiency:}




\section{Shams et al.}

Results of economic efficiency are shown in Table (7). Average daily feed cost tended to increase with chlorella supplementation. Feed cost per one $\mathrm{kg}$ live weight gain decreased significantly $(\mathrm{P}<0.05)$ with chlorella supplemented rations. Group 1 recorded significantly $(\mathrm{P}<0.05)$ the highest feed cost $/ \mathrm{kg}$ gain followed by $\mathrm{G} 2$, but G3 had the lowest value. In the other side, total and net revenue and economic efficiency improved significantly $(\mathrm{P}<0.05)$ with all chlorella supplemented rations. High chlorella level $(\mathrm{G} 3$ and G5) recorded significantly $(\mathrm{P}<0.05)$ the highest total and net revenue and economic efficiency followed by low chlorella level (G2 and G4), while, the control group (G1) had the lowest values. These results are in reflection of the potential improvements in ADG with chlorella supplementation (Table 6). These results in agreement with those obtained by El-Abd and Hamouda (2017) who found that economic efficiency of birds treated with chlorella algae was superior to that of the control group.

Table (7): Feed conversion and economic efficiency of calves fed the different experimental rations.

\begin{tabular}{lcccccc}
\hline \multirow{2}{*}{ Item } & \multicolumn{5}{c}{ Experimental group } & \multirow{2}{*}{ SEM } \\
\cline { 2 - 6 } & G1 & G2 & G3 & G4 & G5 & \\
\hline Feed conversion (kg/kg gain) & & & & & & \\
DM & $2.55^{\mathrm{a}}$ & $2.32^{\mathrm{b}}$ & $2.16^{\mathrm{c}}$ & $2.29^{\mathrm{b}}$ & $2.18^{\mathrm{c}}$ & 0.03 \\
TDN & $1.93^{\mathrm{a}}$ & $1.81^{\mathrm{b}}$ & $1.74^{\mathrm{c}}$ & $1.78^{\mathrm{b}}$ & $1.74^{\mathrm{c}}$ & 0.02 \\
DCP & $0.337^{\mathrm{a}}$ & $0.316^{\mathrm{b}}$ & $0.303^{\mathrm{c}}$ & $0.310^{\mathrm{b}}$ & $0.304^{\mathrm{c}}$ & 0.00 \\
& & & & & & 3 \\
Economic efficiency & & & & & & \\
Feed cost (LE/day) & 22.16 & 22.62 & 23.12 & 22.62 & 23.12 & 0.08 \\
Feed cost (LE/kg gain) & $46.63^{\mathrm{a}}$ & $43.44^{\mathrm{b}}$ & $41.27^{\mathrm{c}}$ & $42.83^{\mathrm{bc}}$ & $41.58^{\mathrm{bc}}$ & 0.47 \\
Total revenue (LE) & $33.27^{\mathrm{c}}$ & $36.45^{\mathrm{b}}$ & $39.22^{\mathrm{a}}$ & $36.98^{\mathrm{b}}$ & $38.92^{\mathrm{a}}$ & 0.51 \\
Net revenue (LE) & $11.11^{\mathrm{c}}$ & $13.83^{\mathrm{b}}$ & $16.10^{\mathrm{a}}$ & $14.36^{\mathrm{b}}$ & $15.81^{\mathrm{a}}$ & 0.44 \\
Economic efficiency & $1.50^{\mathrm{c}}$ & $1.61^{\mathrm{b}}$ & $1.70^{\mathrm{a}}$ & $1.64^{\mathrm{ab}}$ & $1.68^{\mathrm{a}}$ & 0.02 \\
Economic efficiency*, $\%$ & $50.13^{\mathrm{c}}$ & $61.14^{\mathrm{b}}$ & $69.64^{\mathrm{a}}$ & $63.48^{\mathrm{b}}$ & $68.38^{\mathrm{a}}$ & 1.72 \\
\hline
\end{tabular}

$a, b$ and $c$ : Values in the same row with different superscripts differ significantly $(P<0.05)$.

* Economic efficiency, \% = net revenue x 100/ feed cost.

\section{CONCLUSION}

Based on these results it could be concluded that chlorella algae supplementation with their media for diet of suckling calves at the level of $4 \mathrm{ml} / \mathrm{kg}$ live body weight potentially improved digestibility, feed intake, blood serum biochemical, immunity, daily gain, feed conversion and economic efficiency. Using milk of cows supplemented with algae in suckling calves did not have any significant effects on their growth performance.

\section{REFERENCES}

Abedin, Rania M.A. and Hala M. Taha (2008). Antibacterial and antifungal activity of cyanobacteria and green microalgae. Evaluation of medium components by Plackett-Burman design for antimicrobial activity of Spirulina platensis. Global J. Biotechnol. Biochem., 3: 22-31.

Anele, U.Y.; W.Z. Yang; P.J. Mcginn; S.M. Tibbetts and T.A. McAllister (2016). Ruminal in vitro gas production, dry matter digestibility, methane abatement potential and fatty acid biohydrogenation of six species of microalgae. Canadian J. Anim. Sci., 96: 354-363.

AOAC (2000). Official Methods of Analysis, 17th Ed. Association of Official Analytical Chemists, Washington, DC, USA.

Becker, W. (2004). Microalgae for Aquaculture: The Nutritional Value of Microalgae for Aquaculture. In: Richmond, A. (eds.): Handbook of Microalgal Culture: Biotechnology and Applied Phycology. Oxford, pp. 380-391.

Duncan, D.B. (1955). Multiple range and multiple F-test. Biometrics, 11:1-42. 
El-Abd, Niamat M. and Ragaa A. Hamouda (2017). Improved Productivity and Health of Broiler Chicken by Micro Green Alga Chlorella vulgaris. Asian J. Poult. Sci., 11(2): 57-63.

El-Sayed, A.B.; M.G. Battah and E. Wehedy (2015). Utilization efficiency of artificial carbon dioxide and corn steam liquor by Chlorella vulgaris. Biolife, 3: 391-402.

El-Sayed, A.E.B.; F.E. Abdalla and A.A. Abdel-Maguid (2001). Use of some commercial fertilizer compounds for Scenedesmus cultivation. Egyptian Journal of Phycology, 2: 9-16.

Glover, K.E.; S. Budge; M. Rose; H.P.V. Rupasinghe; L. Maclaren; J. Green-Johnson and A.H. Fredeen (2012). Effect of feeding fresh forage and marine algae on the fatty acid composition and oxidation of milk and butter. J. Dairy Sci., 95: 2797-2809.

Goüveia, L.; A.P. Batista; I. Sousa; Gouveia, L.; A.P. Batista; I. Sousa N.M. Bandarra and A. Raymundo (2008). Microalgae in Novel Food Products. In: Papadopoulos, K.N. (ed.): Food Chemistry Research Developments. Hauppauge, NY, pp. 1-37.

Guroy, D.; B. Guroy; D.L. Merrifield; S. Ergun; A.A. Tekinay and M. Yigit (2011). effect of dietary ulva and spirulina on weight loss and body composition of rainbow trout, oncorhynchus mykiss (walbaum), during a starvation period. Journal of Animal Physiology and Nutrition, 95(3): 320-327.

Guzmán, S.; A. Gato and J.M. Calleja (2001). Antiinflammatory, analgesic and free radical scavenging activities of the marine microalgae Chlorella stigmatophora and Phaeodactylum tricornutum. Phytother Res., 15: 224-230.

Guzman, S.; A. Gato; M. Lamela; M. Faerie-Garabal and J.M. Calleja (2003). Anti-inflammatory and immunomodulatory activities of polysaccharide from Chlorella stigmatophora and Phaeodactylum tricornutum. Phytother. Res., 17: 655-670.

Halama, D. (1990). Single cell protein. In: Nonconventional Feedstuffs in the Nutrition of Farm Animals (Ed. K. Boda). Elsevier Science Publishing Company, Inc. 655 Avenue of Americas, New York, N.Y. 10010. pp. 34-49.

Han, J.G.; G.G. Kang; J.K. Kim and S.H. Kim (2002). The present status and future of Chlorella. Food Science and Industry, 6: $64-69$.

Hosten, A.O. (1990). BUN and creatinine. In Clinical Methods: The History, Physical, and Laboratory Examinations, $3^{\text {rd }}$ Ed. (Eds H.K. Walker, W.D. Hall and J.W. Hurst), pp. 874-878. Boston, UK: Butterworths.

IBM SPSS Statistics (2014). Statistical package for the social sciences, Release 22, SPSS INC, Chicago, USA.

Iwamoto, H. (2004).Industrial production of microalgal cell-mass and secondary products - major industrial species. Chlorella. In Handbook of Microalgal Culture: Biotechnology and Applied Phycology (Ed. A. Richmond), pp. 255-263. Oxford, UK: Blackwell Science.

Jahn, S.; D. Sparborth and H.J. Thieme (1995). Investigation of economic efficiency from Chlorella biomass in the piglet production. In: Abstracts of 2nd European Workshop Biotechnology of Microalgae, September 11-12, Bergholz-Rehbrücke, Germany, pp 108-111.

Janczyk, P.; B. Halle and B. Souffrant (2009). Microbial community composition of the crop and ceca contents of laying hens fed diets supplemented with Chlorella vulgaris. Poult. Sci., 88: 2324-2332.

Janczyk, P.; M. Langhammer; U. Renne; V. Guiard and W.B. Souffrant (2006). Effect of feed supplementation with Chlorella vulgaris powder on mice reproduction. Archiva Zootechnica, 9: 122-134.

Kang, H.K.; H.M. Salim; N. Akter; D.W. Kim; H.T. Bang; M.J. Kim; J.C. Na; J. Hwangbo; H.C. Chol and O.S. Suh (2013) Effect of various forms of dietary Chlorella supplementation on growth performance, immune characteristics and intestinal microflora population of broiler chickens. J. Appl. Poultry Res., 22: 100-108.

Kholif, A.E.; T.A. Morsy; O.H. Matloup; U.Y. Anele; A.G. Mohamed and A.B. El-Sayed (2017). Dietary Chlorella vulgaris microalgae improves feed utilization, milk production and concentrations of conjugated linoleic acids in the milk of Damascus goats. Journal of Agricultural Science, 155: 508-518. 


\section{Shams et al.}

Kotrbáček, V.; J. Doubek and J. Doucha (2015). The chlorococcalean alga Chlorella in animal nutrition: a review. J. Applied Phycology, 27: 2173-2180.

Michiels, J.; E. Skrivanova; J. Missotten; A. Ovyn; J. Mrazek; S. De Smet and N. Dierick (2011). Intact brown seaweed (Ascophyllum nodosum) in diets of weaned piglets: effects on performance, gut bacteria and morphology and plasma oxidative status. Journal of Animal Physiology and Animal Nutrition, doi: 10.1111/j.1439-0396.2011.01227.

Mustafa, M.G. and H. Nakagawa (1995). A review: Dietary benefits of algae as an additive in fish feed. Israeli Journal of Aquaculture-Bamidgeh., 47: 155-162.

Nakagawa, H. (1997). Effect of dietary algae on improvement of lipid metabolism in fish. In: Biomedicine and Pharmacotherapy, 51(8): 345-348.

Nath, P.R.; I. Khozin-Goldberg; Z. Cohen; S. Boussiba and D. Zilberg (2012). Dietary supplementation with the microalgae parietochloris incisa increases survival and stress resistance in guppy (poecilia reticulate) fry. Aquaculture Nutrition, 18(2): 167-180.

NRC (2001). Nutrient requirements of dairy cattle. National Academy Press, Washington, D.C., USA.

NRC (2011). Nutrient requirements of fish and shrimp. National Academies Press, Washington D.C., USA.

Patnaik, S.; T.M. Samocha; D.A. Davis; R.A. Bullis and C.L. Browdy (2006). The use of HUFA-rich algal meals in diets for Litopenaeus vannamei. Aquaculture Nutrition, 12: 395-401.

Phang, S.M. (1992). Role of algae in livestock-fish integrated farming system. Proceedings of the FAO/IPT Workshop on Integrated Livestock-Fish Production System (Ed. T. K. Mukherjee, P. S. Moi, J. M. Panandam and Y. S. Yang); 16-20 Dec., 1991, University of Malaya, Kuala Lumpur, Malaysia. pp. 4956.

Pulz, O. and W. Gross (2004). Valuable Products from Biotechnology of Microalgae. In: Applied Microbiology and Biotechnology, 65(6): 635-648.

Radhakrishnan,S.; P.S. Bhavan; C. Seenivasan; R. Shanthi and T. Muralisankar (2014). Replacement of fishmeal with Spirulina platensis, Chlorella vulgaris and Azolla pinnata on non-enzymatic and enzymatic antioxidant activities of Macrobrachium rosenbergii. Journal of Basic and Applied Zoology, 67: 25 -33.

Redel, H. and U. Buchta (2001a). Effect of algae biomass ongrowth of Peking ducks. Results of production in farm Neuhardenberg. Jahresbericht Landesanstalt Landwirtschaft Brandenburg, 5:109-111 (in German).

Redel, H. and U. Buchta (2001b). Effect of algae biomass on reproduction of Peking ducks. Jahresbericht Landesanstalt Landwirtschaft Brandenburg, 5:112-113 (in German).

Regunathan, C. and S.G. Wesley (2006). Pigment deficiency correction in shrimp broodstock using Spirulina as a carotenoid source. Aquac. Nutr., 12: 425-432.

Scheffler, J. (2007). Under water Habitats. Illumin, 9 (4).

Schneider, B.H. and W.P. Flatt (1975). The evaluation of feeds through digestibility experiments. The University of Georgia press Athens, 3: 602-610.

Sheikhzadeh, N.; H. Tayefi-Nasrabadi; A. Khani Oushani and M.H. Najafi Enferadi (2012). Effects of haematococcus pluvialis supplementation on antioxidant system and metabolism in rainbow trout (Oncorhynchus mykiss). In: Fish Physiology and Biochemistry, 38(1): 413-419.

Stainer, R.Y.; R. Kunisawa; M. Mandel and G. Cohen-Bazire (1971). Purification and properties of unicellular blue green algae (order Chroococcales). Bacteriological Reviews, 35: 171-205.

Storandt, R.; O. Pulz and H. Franke (2000). Algae in animal production. In: Institut für Tierernährung Braunschweig (ed): Expo 2000 Workshop (FAL). Braunschweig, Germany, p 31 (in German).

Takeuchi, T.; J. Lu; G. Yoshizaki and S. Satoh (2002). Effect on the growth and body composition of juvenile tilapia Oreochromis niloticus fed raw Spirulina. Fisheries Science, 68, 34-40. 
Taranu, I.; D.E. Marin; A. Untea; P. Janczyk; M. Motiu; R.D. Criste and W.B. Souffrant (2012). Effect of dietary natural supplements on immune response and mineral bioavailability in piglets after weaning. Czech J. Anim. Sci., 57(7): 332-343.

Tibbetts, S.M.; J.E. Milley and S.P. Lall (2016). Nutritional quality of some wild and cultivated seaweeds: Nutrient composition, total phenolic content and in vitro digestibility. J. Appl. Phycol., 28(6): 3575 3585.

Tsiplakou, E.; M.A.M. Abdullah; D. Skliros; M. Chatzikonstantinou; E. Flemetakis; N. Labrou and G. Zervas (2016). The effect of dietary Chlorella vulgaris supplementation on micro-organism community, enzyme activities and fatty acid profile in the rumen liquid of goats. Journal of Animal Physiology and Animal Nutrition, 101(2): 275-283.

Turner, J.L.; S.S. Dritz; J.J. Higgins and J.E. Minton (2002). Effects of ascophyllum nodosum extract on growth performance and immune function of young pigs challenged with salmonella typhimurium. J. Anim. Sci., 80(7): 1947-1953.

Van Keulen and Young (1977). Evaluation of acid insoluble ash as a natural marker in ruminant digestibility studies. J. Animal. Sci., 44: 282.

Yan, L.; S.U. Lim and I.H. Kim (2012). Effect of fermented chlorella supplementation on growth performance, nutrient digestibility, blood characteristics, fecal microbial and fecal noxious gas content in growing pigs. Asian-Aust. J. Anim. Sci., 25(12): 1742-1747.

Zeinhom, M.M. (2004). Nutritional and physiological studies on fish. Ph. D. Thesis. Faculty of Agriculture, Zagazig University. Egypt.

Zheng, L.; S. Oh; J.Y. Jeon; B.H. Moon; H.S. Kwon; S.U. Lim; B.K. An and C.W. Kang (2012). The dietary effects of fermented Chlorella vulgaris on production performance, liver lipids and intestinal microflora in laying hens. Asian-Aust. J. Anim. Sci., 25, 261-266. 


\title{
تأثير اضافة طحلب كلوريلا فولجاريس على الأداء الانتاجى للعجول الفريزيان الرضيعة
}

\author{
أحمد شعبان شمس1، محمه السيد سيدأحمد1، مصطفى محمد النحراوى1، عبدالجواد يوسف السعدنى²

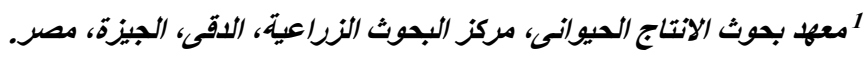

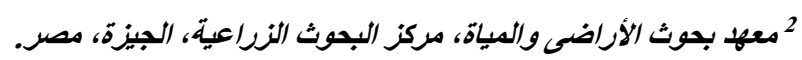

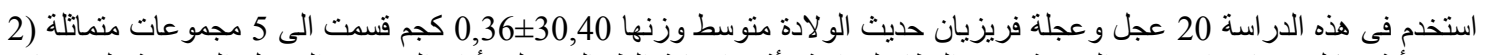

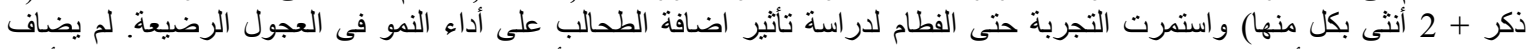

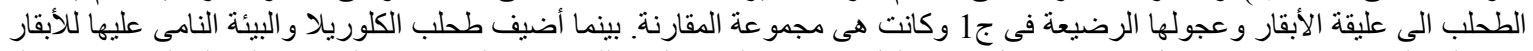

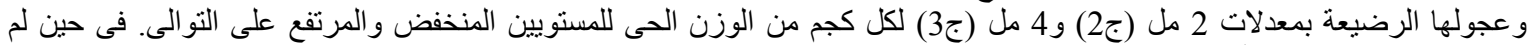
يضاف طحلب الكلوريلا لأبقار ج4 و ج5، ولكن ولكن تم اضافته للعجول الرضيعة بنفس المعدلات السابقة.

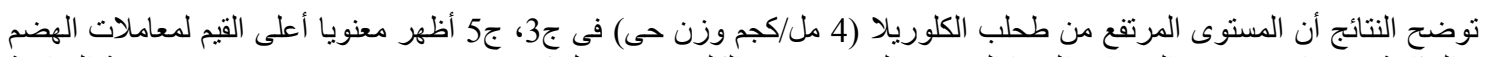

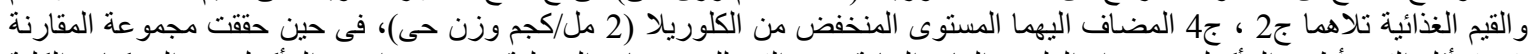

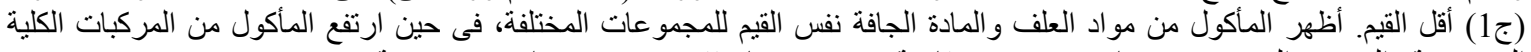

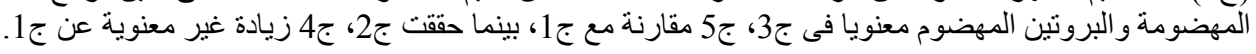

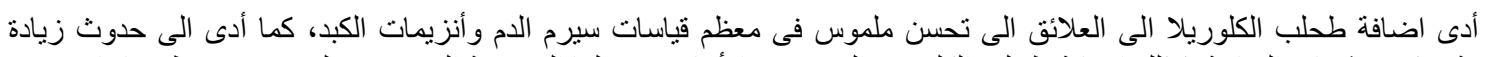

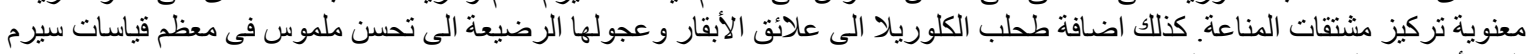
الام و أنزيمات الكبد ومشتقات المناعة.

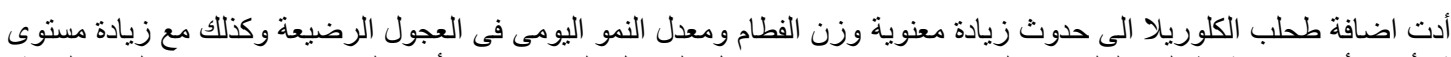

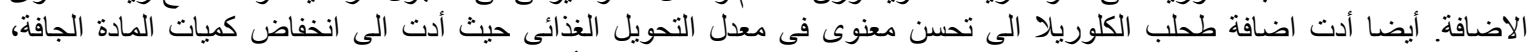

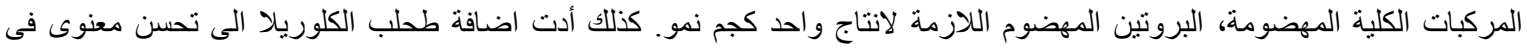

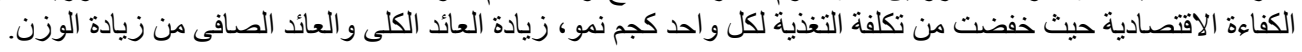

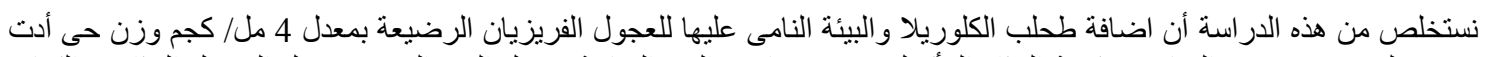

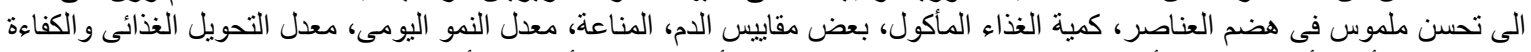
الاقتصادية. وأيضا أكلت الدراسة أن اضافة طحلب الكلوريلا الى علائق الأبقار ليس له تأثئير على أداء النمو للعجول الرضيعة. 